\title{
Elevation of Tissue Coenzyme Q (Ubiquinone) and Cytochrome $c$ Concentrations by Endurance Exercise in the Rat ${ }^{1}$
}

\author{
ROBERT E. BEYER, ${ }^{2}$ PEDRO G. MORALES-CORRAL, ${ }^{3}$ BOBBI J. RAMP, \\ KEVAN R. KREITMAN, MICHAEL J. FALZON, STEPHEN YUNG SHIK RHEE, \\ THOMAS W. KUHN, MONA STEIN, MITCHELL J. ROSENWASSER, \\ AND KENNETH J. CARTWRIGHT
}

\author{
Laboratory of Chemical Biology, Department of Cellular and Molecular Biology, Division of Biological \\ Sciences, University of Michigan, Ann Arbor, Michigan 48109-1048
}

Received April 11, 1984, and in revised form June 25, 1984

Six months of enforced and voluntary endurance training of young female Wistar rats resulted in significant decreases of body weight and gastrocnemius muscle wet weight and protein content, and increases in heart weight and protein content, and liver protein content. The coenzyme $Q$ and cytochrome $c$ concentrations of cardiac, gastrocnemius, and deep red region of the vastus lateralis muscles were increased, while small or nonsignificant trends toward increases in cytochrome $c$ and coenzyme $Q$ were seen in kidney, brain, lung, liver, internal + external oblique muscles, and the superficial white region of the vastus lateralis muscle. These results are discussed with regard to several roles for coenzyme $Q$ in cellular function. Q 1984 Academic Press, Ine.

Skeletal muscle adapts to prolonged endurance training by a large number of biochemical modifications (1), including the synthesis of an increased number of mitochondria $(2,3)$. As a consequence, skeletal muscle adapted to endurance training contains elevated concentrations of cytochrome $c^{4}(4,5)$, flavin $(3)$, and an increased capacity to catalyze the oxidation of pyruvate (6), long-chain fatty acids $(6,7)$, and $\beta$-hydroxybutyrate and acetoacetate (8). The increased requirement for oxygen delivery to the mitochondrial cy-

\footnotetext{
1 This paper is dedicated to the memory of Professor David Ezra Green, an inspiration to many of us researching the biochemistry of biological energy transfer mechanisms.

${ }^{2}$ To whom correspondence should be addressed.

${ }^{8}$ Present address: Departamento de Medicina del Deporte y Rehabilitacion, Universidad Autonoma de Neuvo Leon, Monterrey, N.L., Mexico.

Abbreviations used: cyt. c, cytochrome c; CoQ, coenzyme Q; TES, 2-\{[2-hydroxy-1,1-bis(hydroxymethyl)ethyl]amino\}-1-propanesulfonic acid; SVL, superficial white vastus lateralis (Type IIB); DVL, deep red vastus lateralis (Type IIA).
}

tochrome oxidase is aided by an increased skeletal muscle concentration of myoglobin $(9,10)$. A very significant number of enzymes catalyzing individual steps of $\beta$ oxidation of fatty acids, the tricarboxylic acid cycle, the electron transport chain, oxidative phosphorylation and associated transport, and synthetic reactions have also been reported to respond to endurance exercise training (cf (1) for a review). Mitochondria isolated from muscle of trained animals appear normal with respect to oxidative catalytic activity, oxidative phosphorylation efficiency, and respiratory control $(3,11-13)$.

Coenzyme $Q^{5}(\mathrm{CoQ})$ is an obligatory

\footnotetext{
${ }^{5}$ We prefer the term coenzyme $Q$ to ubiquinone for the following reasons: (i) The term ubiquinone implies that the compound is ubiquitous (14). It is not present in a number of organisms (15) including gram-positive bacteria (16) and some fungi (17). It is also not present in methanogenic bacteria (18); (ii) A coenzymatic function for this benzoquinone, originally suggested by Green (19), has recently received considerable experimental support (20-22) by the isolation of mitochondrial $\mathrm{CoQ}$ apoproteins
} 
member of the mitochondrial electron transport chain (23), and has a regulatory effect on mitochondrial succinate dehydrogenase (24-27), NADH dehydrogenase $(28,29)$, and the cytochrome $b-c_{1}$ complex (30-32). CoQ has been postulated (33-35) as serving as a "proton motive $Q$ cycle," instrumental in conserving energy released by oxidation-reduction reactions of the electron transport chain in the establishment of an inner mitochondrial transmembrane proton gradient. Despite the importance of this benzoquinone, no studies have been published on the effect of endurance training on CoQ tissue concentrations. This study reports such data on CoQ together with alterations observed on tissue cyt $c$ concentrations.

\section{EXPERIMENTAL PROCEDURES}

Exercise protocol. Six-week-old, pathogen-free female Wistar rats were obtained from Charles River Breeding Laboratories and housed in a temperaturecontrolled room $\left(20^{\circ} \mathrm{C}\right)$ free of other rodent species. The animals were maintained within the guidelines of the American Physiological Society. At the age of 2 months, a group of rats entered a forced training program and were housed in exercise wheel cages (Wahmann Rodent Activity Cages) for the remainder of the training period. All animals received Purina Rat Chow (No. 5001, Ralston Purina Co.) and water ad libitum. The animals were trained in a 10channel, motor-driven rodent treadmill (Model 4215, Quinton Instruments, Seattle, Wash.). Throughout the exercise program, the treadmill angle of incline was $8^{\circ}(15 \%)$. Treadmill running was reinforced by an overhead air jet and, when necessary, mild electric shock. All exercising animals ran 5 days/week for a 6 -month period. During the first week of training, the animals ran between 15 and $30 \mathrm{~min}$ at a rate of $26.8 \mathrm{~m} / \mathrm{min}(1 \mathrm{mile} / \mathrm{h})$. The duration was increased daily until the rats were running at this rate for $120 \mathrm{~min}$ by the 10th day of training. This protocol was maintained for the remainder of the 6-month training period.

At the beginning of the training period, the animals ran voluntarily in their exercise wheels a mean

or binding proteins. (iii) The objection to the use of CoQ on the basis that it may be confused by students of biochemistry with a coenzyme of Q-enzyme (15) is no longer valid since this term for amylo $(1,4-1,6)$ trans-glycosylase is not found in modern texts of biochemistry. In fact, a survey of modern textbooks of biochemistry indicates that the designation Coenzyme $Q$ is preferred. distance of approximately $7 \mathrm{miles} /$ day, decreasing gradually to between 1.5 and 2 miles/day at the end of the 6-month training period. This level of voluntary running activity has been reported previously $(36,37)$.

Tissue preparation Animals were anesthetized with sodium pentoharbital $(40 \mathrm{mg} / \mathrm{kg}$, ip). Tissues were removed and placed immediately in ice-cold isotonic medium (4) consisting of $50 \mathrm{mM}$ TES, 100

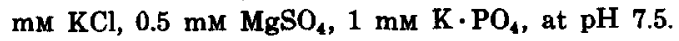
The tissues were rinsed with ice-cold isotonic medium until free of blood, and blotted dry and weighed. Tissues selected for analysis were heart (ventricles), kidneys, brain, liver, and lung, and gastrocnemius, internal + external oblique, and vastus lateralis muscles. The vastus lateralis muscles were separated into deep red region type IIA (DVL) and superficial white region type IIB (SVL) portions, and the two were analyzed separately. Tissues were analyzed immediately or stored frozen.

Immediately prior to analysis, a volume of cold distilled water equal to five (heart) or two (all other tissues) times the wet weight of the tissue was added, and the tissue was minced and then homogenized for between 90 and $120 \mathrm{~s}$ with a Willem's UltraTurrax homogenizer (Model BEW, Janke and Kunkel, AB) operated at $60 \%$ maximum speed. This procedure also removes the bulk of connective tissue.

Assays. Tissue protein concentration was determined in triplicate by a biuret procedure (38). Crystalline bovine serum albumin, used as standard, was prepared and standardized according to Kaziro et al. (39). Tissue $\mathrm{CoQ}$ concentrations were analyzed in triplicate by the procedure of Kroger (40). An attempt to utilize a single-blind approach to $\mathrm{CoQ}$ analyses was obviated by the conspicuous differences between sedentary and trained animals with respect to hind limb muscle coloration due to increased concentrations of hemoglobin, myoglobin, and cytochromes. Cyt. $c$ was determined in triplicate according to the procedures of Aschenbrenner et al. (41) or Williams and Thorp (42). These two procedures gave comparable results in the concentration range previously published (43) for cardiac muscle.

Statistical analysis. Statistical confidence intervals between group means were determined according to Student's small-sample $t$ test (44). Two-tailed $t$ tests were used unless a trend could be predicted a priori, in which case a one-tailed $t$ test was applied. All data are reported as means \pm standard error of the mean.

\section{RESULTS}

\section{Body Weight}

Six months of enforced endurance training, coupled with the opportunity to run voluntarily, produced a group of 
trained rats whose mean body weights were $87.9 \%$ of the sedentary control group, a difference statistically significant at the 99.9\% level of confidence (Table I). That the body weight difference between the trained and sedentary groups reported in Table I was a direct result of the experimental condition is supported by a lack of body weight difference between the groups at the beginning of the training period (Table I). This body weight differential between trained and sedentary rats is a common observation $(3,9,36,45-47)$.

The effect of endurance training on tissue weights and protein contents is reported in Table II. As has been observed previously (48-50), treadmill training in rodents results in cardiac hypertrophy, reflected as an increase in the weight of the heart and its content of protein but not its protein concentration (Table II). Endurance exercise-induced cardiac hypertrophy is more pronounced in female rats than in males (49), and may not be observed in elderly rats trained with a milder training protocol (43).

Although training did not affect liver weight, the protein content and concentration of the liver was increased 60 and $51 \%$, respectively, in the trained group. Small increases in lung weight and protein content in the trained group were also observed (Table II). No alterations as a result of training occurred in the weights or protein contents of the kidneys or brain. On the other hand, the wet weight, protein content, and protein concentration of gastrocnemius muscle, a tissue directly

\section{TABLE I}

Body Weights of TRanNed and SEDENTARY Rats Before and after a 6-Month Training Period

\begin{tabular}{lccc}
\hline & $\begin{array}{c}\text { Sedentary } \\
(n=9)\end{array}$ & $\begin{array}{c}\text { Trained } \\
(n=13)\end{array}$ & $P$ \\
\hline $\begin{array}{c}\text { Before } \\
\text { training }\end{array}$ & $184.3 \pm 3.0^{a}$ & $183.1 \pm 2.9$ & NS $^{b}$ \\
$\begin{array}{c}\text { After } \\
\text { training }\end{array}$ & $317.7 \pm 19.3$ & $279.4 \pm 29.0$ & $<0.001$ \\
\hline
\end{tabular}

${ }^{a}$ Grams \pm standard error of the mean.

${ }^{b}$ Not significant, $P>0.1$. involved in locomotor activity, decreased significantly in the trained group (Table II).

The effect of endurance training on tissue CoQ and cyt. $c$ concentrations is reported in Tables III and IV. Training resulted in highly significant $\mathrm{CoQ}$ and cyt. $c$ increases in cardiac tissue calculated with reference to both wet weight and protein content. Although not listed in Table III, it is of interest to note that training increased the CoQ content of the whole heart from $198 \pm 13$ to $270 \pm 10$ $\mathrm{nmol} /$ heart, an increase of $36 \%$, significant at the $99.9 \%(P<0.001)$ level of confidence. Endurance training also produced large and statistically significant increases in both $\mathrm{CoQ}$ and cyt. $c$ concentrations of gastrocnemius and DVL muscles (Tables III and IV). Exercise training did not appear to affect $\mathrm{CoQ}$ and cyt. $c$ concentrations in kidney, liver, brain, or SVL muscle. With the exception of the kidney, these tissues tended toward small, but not significant, elevations of $\mathrm{CoQ}$ and cyt. $c$, some of which were statistically significant when a one-tailed analysis of significance was applied (Tables III and IV).

\section{DISCUSSION}

It has been known for more than 20 years that manipulations of the intact animal which alter overall respiratory metabolism also result in changes in tissue CoQ concentrations $(51,52)$. Such changes are in the same direction as those in respiratory metabolism. No information is available on the effect of endurance exercise on tissue CoQ concentrations, despite reports that the oral administration of $\mathrm{CoQ}$ in humans improved exercise performance both in patients with ischemic heart disease (53) and in normal individuals (54). As reported in Tables III and IV, the exercise protocol used, including both enforced exercise and a surprisingly high level of nocturnal voluntary running, resulted in significant parallel increases in $\mathrm{CoQ}$ and cyt. $c$ in cardiac, gastrocnemius, and deep vastus lateralis muscle. Each is functionally involved in the increased physical activity of endurance training. 
TABLE II

Effect of Endurance Training on Tissue Weights and Protein Contents

\begin{tabular}{|c|c|c|c|}
\hline Tissue & Sedentary & Trained & $P$ \\
\hline & \multicolumn{2}{|c|}{ Wet weight (g) } & \\
\hline Heart & $0.805 \pm 0.026^{a}(9)^{b}$ & $0.950 \pm 0.034$ & $<0.01$ \\
\hline Kidney & $1.996 \pm 0.060$ & $1.985 \pm 0.065$ (13) & $\mathrm{NS}^{d}$ \\
\hline Brain & $1.883 \pm 0.034$ & $1.879 \pm 0.028$ & NS \\
\hline Liver & $10.730 \pm 0.582$ & $11.552 \pm 0.648$ & NS \\
\hline Lung & $1.238 \pm 0.026$ & $1.373 \pm 0.088$ & $<0.01^{\circ}$ \\
\hline \multirow[t]{3}{*}{ Gastrocnemius } & $3.932 \pm 0.109$ & $3.388 \pm 0.099$ & $<0.01$ \\
\hline & \multicolumn{2}{|c|}{ Protein content $(\mathrm{mg})$} & \\
\hline & $138 \pm 13$ & $167 \pm 13$ & $<0.01^{\circ}$ \\
\hline Kidney & $303 \pm 32$ & $302 \pm 15$ & NS \\
\hline Brain & $183 \pm 14$ & $179 \pm 12$ & NS \\
\hline Liver & $1451 \pm 124$ & $2315 \pm 190$ & $<0.01$ \\
\hline Lung & $183 \pm 15$ & $218 \pm 23$ & $<0.02^{c}$ \\
\hline \multirow[t]{2}{*}{ Gastrocnemius } & $830 \pm 93$ & $586 \pm 28$ & $<0.02$ \\
\hline & \multicolumn{2}{|c|}{ Protein concentration (mg/g tissue) } & \\
\hline Heart & $184 \pm 11$ & $175 \pm 11$ & NS \\
\hline Kidney & $151 \pm 14$ & $153 \pm 8$ & NS \\
\hline Brain & $97 \pm 7$ & $96 \pm 7$ & NS \\
\hline Liver & $134 \pm 7$ & $203 \pm 20$ & $<0.01$ \\
\hline Lung & $148 \pm 12$ & $157 \pm 10$ & NS \\
\hline Gastrocnemius & $229 \pm 14$ & $169 \pm 7$ & $<0.01$ \\
\hline
\end{tabular}

${ }^{a}$ Mean \pm SE.

${ }^{b}$ The number of observations in parentheses.

' Significance with one-tailed analysis of $t$, NS with two-tailed analysis.

${ }^{d}$ Not significant; $P>0.05$.

\section{TABLE III}

Tissue Coenzyme $Q$ Concentrations with Training

\begin{tabular}{|c|c|c|c|c|c|c|c|}
\hline \multirow[b]{2}{*}{ Tissue } & \multicolumn{4}{|c|}{$\mathrm{nmol} \mathrm{CoQ} \cdot \mathrm{g}$ wet $\mathrm{wt}^{-1} \pm \mathrm{SE}$} & \multicolumn{3}{|c|}{ pmol CoQ $\cdot \mathrm{mg}$ protein ${ }^{-1} \pm \mathrm{SE}$} \\
\hline & Sedentary & Traine & & $\boldsymbol{P}$ & Sedentary & Trained & $P$ \\
\hline Heart & $205 \pm 13(9)^{a}$ & $289 \pm 9$ & (13) & $<0.001$ & $1078 \pm 99$ & $1841 \pm 120$ & $\ll 0.001$ \\
\hline Kidney & $142 \pm 11(8)$ & $125 \pm 9$ & (13) & $\mathbf{N S}^{b}$ & $921 \pm 69$ & $824 \pm 50$ & NS \\
\hline Bra & $34 \pm 5$ & $47 \pm 5$ & (13) & NS & $384 \pm 35$ & $485 \pm 46$ & NS \\
\hline un & $20 \pm 2(8)$ & $25 \pm 3$ & (13) & $<0.02^{c}$ & $145 \pm 18$ & $177 \pm 16$ & $<0.02^{e}$ \\
\hline Liver & $153 \pm 38(7)$ & $185 \pm 58$ & (12) & NS & $731 \pm 175(7)$ & $982 \pm 323(12)$ & NS \\
\hline \multicolumn{8}{|l|}{ Internal + external } \\
\hline oblique & $29 \pm 4 \quad(8)$ & $33 \pm 2$ & (12) & $\mathbf{N}$ & $197 \pm 45$ & $15 \quad(12)$ & NS \\
\hline Gastroenemius & $48 \pm 4$ & $73 \pm 3$ & (13) & $<0.001$ & $231 \pm 14$ & $457 \pm 28$ & $<0.001$ \\
\hline SVL $^{d}$ & $40 \pm 8$ & $47 \pm 8$ & (12) & NS & $225 \pm 49$ & $324 \pm 58$ & $<0.02^{c}$ \\
\hline $\mathbf{D V L}^{d}$ & $74 \pm 11(8)$ & $121 \pm 8$ & (13) & $<0.01$ & $348 \pm 57 \quad(8)$ & $715 \pm 60$ & $<0.001$ \\
\hline
\end{tabular}

${ }^{a}$ Number of observations; analyses in triplicate.

${ }^{b}$ Not significant, $P>0.05$ with two-tailed analysis of $t$.

' One-tailed analysis of $t, P>0.05$ with two-tailed analysis of $t$.

${ }^{d}$ Superficial and deep vastus lateralis muscle portions. 
TABLE IV

Tissue Cytochrome $c$ Concentrations WITH TRAINING

\begin{tabular}{|c|c|c|c|}
\hline \multirow[b]{2}{*}{ Tissue } & \multicolumn{3}{|c|}{ pmol cyt. $c \cdot \mathrm{mg}$ protein ${ }^{-1} \pm \mathrm{SE}^{c}$} \\
\hline & Sedentary & Trained & $\boldsymbol{P}$ \\
\hline Heart & $282.4 \pm 5.5$ & $476.7 \pm 13.2$ & $<0.001$ \\
\hline Kidney & $172.9 \pm 9.9$ & $156.0 \pm 8.4$ & $\mathbf{N S}^{b}$ \\
\hline Brain & $57.6 \pm 3.4$ & $65.2 \pm 2.5$ & $<0.01^{c}$ \\
\hline Lung & $38.6 \pm 2.1$ & $46.9 \pm 2.7$ & $<0.05$ \\
\hline Liver & $149.6 \pm 7.5$ & $164.5 \pm 6.3$ & NS \\
\hline $\begin{array}{l}\text { Internal + external } \\
\text { oblique }\end{array}$ & $45.0 \pm 2.7$ & $57.4 \pm 3.2$ & $<0.02$ \\
\hline Gastrocnemius & $63.9 \pm 2.4$ & $123.9 \pm 11.6$ & $<0.001$ \\
\hline SVL $^{d}$ & $49.0 \pm 3.3$ & $57.2 \pm 5.7$ & $<0.05^{c}$ \\
\hline DVL $^{d}$ & $63.8 \pm 3.9$ & $140.3 \pm 12.3$ & $<0.001$ \\
\hline
\end{tabular}

all analyses in triplicate; $n=6$ for all cytochrome $c$ analyses.

${ }^{b}$ Not significant, $P>0.05$ with two-tailed analysis of $t$.

e One-tailed anaiysis of $t, P>0.05$ with two-tailed analysis of $t$.

'Superficial and deep vastus lateralis muscle portions.

Although the CoQ and cyt. $c$ concentration increase in cardiac, gastrocnemius, and deep vastus lateralis muscle with endurance training were not unexpected, some of the observations on these two electron-transporting components listed in Tables III and IV were. For example, we have reported $(51,52)$ that brain $\mathrm{CoQ}$ concentrations are stable under a variety of conditions, but the extreme length and intensity of training of the animals used in the present experiments appear to have had a slight, although statistically insignificant, effect on brain CoQ and cyt. $c$ concentrations. The same is the case with lung in which the small increases in CoQ were statistically significant only when a one-tailed analysis of $t$ was employed. On the other hand, the increase in cyt. $c$ with endurance training in lung was significant when a two-tailed analysis was used. A trend toward increases in CoQ and cyt. $c$ was observed in superficial vastus lateralis (Tables III and IV). These observations of marginal effects make it tempting to speculate that the stimulus for the synthesis of additional functional mitochondria in a tissue adapting to increased metabolic needs may diffuse, and stimulate the synthesis of membrane components, at sites removed from its origin. Evidence for this type of phenomenon is implied in studies in which direct electrical stimulation of a hindlimb muscle results in an increase in the rate of protein synthesis in both the stimulated and the contralateral limb muscle (Starnes and Beyer, unpublished observations), and the observation (55) that muscle injury results in an increase in protein synthesis at sites other than that injured. Such diffusible protein factors also have been shown to be implicated in cardiac protein synthesis during cardiac hypertrophy (Cardiac Hypertrophy Factor) $(56,57)$ and in bone formation (Bone Morphogenic Protein) (58).

The observed increases in tissue cyt. $c$ and CoQ concentrations are reflections of increased tissue mitochondrial density (2, 3 ), enabling that tissue to function at higher oxidative activity levels for longer periods of time due to elevated rates of oxidative phosphorylation. The question arises as to whether the increase in CoQ with exercise might have other functional significance. It is well known that the reactions of the electron transport chain of mitochondria produce damaging free radicals, and that the rate of $\mathrm{O}_{2}^{-}$production is directly proportional to the rate of mitochondrial oxygen utilization (59). Exhaustive exercise produces a two- to threefold increase in free radical formation and lipid peroxidation in muscle and liver $(60,61)$, and endurance training appears to reduce the susceptibility of tissue to the damaging effects of free radicals and lipid peroxidation (62). The large increase in liver protein concentration with endurance exercise (Table II) may reflect the synthesis of enzymatic detoxification sequences in response to an increase in metabolic byproduct formation. It has also been suggested that free radical-induced damage may provide a stimulus to mitochondrial biogenesis resulting from endurance training (60).

It is tempting to propose that the large increases in muscle $\mathrm{CoQ}$ with endurance exercise may have a function in addition to that in mitochondrial electron transport and oxidative phosphorylation. The increased levels of CoQ may also function 
as an antioxidant and thus protect the inner mitochondrial membrane from damage inflicted by lipid peroxidation and free radical formation. Reports that CoQ administration may protect mitochondria from damage during heart muscle (63) and brain and kidney (64) ischemia, and carbon tetrachloride toxicity (65), and that CoQ is an effective therapeutic agent in clinical congestive heart failure (66), would suggest that intracellular $\mathrm{CoQ}$ may also serve the vital role of removing damaging superoxide radicals (67) which may accumulate during ischemic conditions when blood circulation through tissues is severely restricted. Indeed, the possibility that the high molar ratio of CoQ to other electron transport chain components (Tables III and IV) represents an evolutionary selection as a free radical quencher at the site of free radical formation is an intriguing idea.

\section{ACKNOWLEDGMENTS}

This research received financial support from the Michigan Heart Association and the Cutcheon Fund of The University of Michigan Honors Program. We thank Ms. Margaret Madouse for preparation of the manuscript.

\section{REFERENCES}

1. Holloszy, J. O., AND Booth, F. W. (1976) Annu Rev. Physiol. 38, 273-291.

2. Gollnick, P. D., AND KING, D. W. (1969) Amer. J. Physiol 216, 1502-1509.

3. Beyer, R. E., Starnes, J. W., Edington, D. W., LIPTON, R. J., COMPTON, R. T., III, AND KWASMan, M. A. (1984) Mech. Ageing Dev. 24, 309323.

4. Barnard, R. J., AND Peter, J. B. (1971) J. Appl. Physiol. 31, 904-908.

5. BoOTH, F. W., AND Holloszy, J. O. (1977) J. Biol. Chem. 252, 416-419.

6. BaldWin, K. M., Klinkerfuss, G. H., TeruUng, R. L., MolÉ, P. H., AND HoLloszy, J. O. (1972) Amer. J. Physiol 222, 373-378.

7. MolE, P. A., OsCaI, L. B., AND Holloszy, J. 0. (1971) J. Clin Invest. 50, 2323-2330.

8. WINDER, W. W., BaLdWIN, K. M., AND HollosZY, J. O. (1975) Canad. J. Physiol. Pharmacol. 53, 86-91.

9. Beyer, R. E., and Fattore, J. E. (1984) $J$. Gerontol, in press.

10. Pattengale, P. K., and Holloszy, J. O. (1967) Amer. J. Physiol. 213, 783-785.
11. Davies, K. J. A., Packer, L., ANd Brooks, G. A. (1981) Arch. Biochem. Biophys. 209, 539-554.

12. Barnard, R. J., Edgerton, V. R., AND Peter, J. B. (1970) J. Apph Physiol 28, 762-766.

13. Holloszy, J. O. (1967) J. Biol Chem. 242, 22782282.

14. MORTON, R. A., WILSON, G. M., LowE, J. S., AND LEAT, W. M. F. (1957) Chem. Ind. 1649.

15. MoRTon, R. A. (1961) in Quinones in Electron Transport (Wolstenholme, G. E. W., and O'Connor, C. M., eds.), p. 21, Little, Brown, and Co., Boston.

16. Bishop, D. H. L., PANDYa, K. P., AND King, H. K. (1962) Biochem. J. 83, 606-614.

17. CRANE, F. L. (1965) in Biochemistry of Quinones (Morton, R. A., ed.), pp. 183-206, Academic Press, New York.

18. Thauer, R. K., Jungerman, K., AND Decker, $K$. (1977) Bacteriol Rev. 41, 100-180.

19. GreEn, D. E. (1959) Disc. Faraday Soc. 27, 206216.

20. KING, T. E. (1982) in Function of Quinones in Energy Conserving Systems (Trumpower, B. L., ed.), pp. 3-25, Academic Press, New York.

21. Yu, C. A., AND YU, L. (1980) Biochem Biophys. Res. Commun. 96, 286-292.

22. $\mathrm{YU}, \mathrm{C}$. A., AND $\mathrm{YU}$, L. (1980) Biochim. Biophys. Acta 593, 24-38.

23. Crane, F. L., Hatefi, Y., Lester, R. L., aND WIDMER, C. (1957) Biochim. Biophys. Acta 25, 220-221.

24. Rossi, E., Norling, B., Persson, B., AND ERnSTer, L. (1970) Eur. J. Biochem. 16, 508-513.

25. GUTMAN, M., KEARNEY, E. B., AND SINGER, T. P. (1971) Biochemistry 10, 2726-2732.

26. Gutman, M., Kearney, E. B., and Singer, T. P. (1971) Biochemistry 10, 4763-4770.

27. Gutman, M., and Silman, N. (1974) Mol. Cell. Biochem. 7, 51-58.

28. Gutman, M., Coles, C. J., Singer, T. P., AND CASIDA, J. E. (1971) Biochemistry 10, 20362043.

29. GLAZEK, E., NoRLING, B., AND ERNSTER, L. (1974) FEBS Leth. 46, 123-126.

30. Ernster, I., Lee, I.-Y., Norling, B., and PerssON, B. (1969) Eur. J. Biochem. 9, 299-310.

31. Nelson, B. D., Norling, B., Persson, B., AND ERnster, L. (1971) Biochem. Biophys. Res. Commun. 44, 1312-1329.

32. Nelson, B. D., Norling, B., Persson, B., AND ERNSTER, L. (1972) Biochim. Biophys. Acta 267, 205-210.

33. MгтснеL, P. (1975) FEBS Lett. 56, 1-6.

34. MitcheLl, P. (1975) FEBS Leth 59, 137-139.

35. Mitchell, P. (1975) in Electron Transfer Chain and Oxidative Phosphorylation (Quagliariello, E., Papa, S., Palmieri, F., Slater, E. C., and 
Siliprandi, N., eds.), pp. 305-316, North-Holland, Amsterdam.

36. Slonaker, J. (1912) J. Animal Behav. 2, 20-42.

37. GoodRICK, C. L. (1980) Gerontology 26, 22-33.

38. BEYER, R. E. (1983) Anal Biochem. 129, 483-485.

39. KAZIRO, Y., OCHOA, S., WARNER, R. C., AND CHEN, J.-Y. (1961) J. Biol Chem. 236, 1917-1923.

40. KRoger, A. (1978) in Methods in Enzymology (Fleischer, S., and Packer, L., eds.), Vol. 53, pp. 579-591, Academic Press, New York.

41. Aschenbrenner, V., Zak, R., CutilletTa, A. F., and Rabinowitz, M. (1971) Amer. J. Physiol 217, 1418-1425.

42. Williams, J. N., JR., AND ThoRP, S. L. (1969) Biochim. Biophys. Acta 189, 25-28.

43. Starnes, J. W., Beyer, R. E., AND Edington, D. W. (1983) Amer. J. Physioh 245, H560H566.

44. Finney, D. J. (1980) Statistics for Biologists, pp. 66-87, Chapman and Hall, New York.

45. Beyer, R. E., HuANG, J. C., aND WILshire, G. A. (1984) Exp. Germt, in press.

46. MCCaY, C., MaYnaRD, L., SPERLING, G., AND OsGOOD, H. (1941) J. Nutr. 21, 45-60.

47. Edington, D. W., Cosmas, A., AND McCafferty, W. (1972) J. Geront. 27, 341-343.

48. OsCai, L. B., Molé, P. A., BREI, B., AND Holloszy, J. O. (1971) Amer. J. Physiol 220, 1238-1241.

49. OscaI, L. B., Molé, P. A., AND Holloszy, J. O. (1971) Amer. J. Physiol. 220, 1944-1948.

50. Hickson, R. C., Hammons, G. T., AND Holloszy, J. O. (1979) Amer. J. Physiol 236, H268-H272.

51. Beyer, R. E., Noble, W. M., AND Hirschfeld, T. J. (1962) Biochim. Biophys. Acta 57, 376379.

52. Beyer, R. E., Noble, W. M., and Hirschfeld, T. J. (1962) Canad. J. Biochem. Physiol 40, 511-518.

53. Awata, N., Ishiyama, T., Harada, H., Sawamura, A., Ogura, K., Tanimoto, T., AzUma, J., Masegawa, H., Morita, Y., and YamaMURA, Y. (1980) in Biomedical and Clinical Aspects of Coenzyme Q (Yamamura, Y., Folkers, K., and Ito, Y., eds.), Vol. 2, pp. 247-253, Elsevier/North-Holland, Amsterdam/New York.

54. VanFraechem, J. H. P., AND Folkers, K. (1981) in Biomedical and Clinical Aspects of Coen- zyme Q (Folkers, K., and Yamamura, Y., eds.), Vol. 3, pp. 235-241, Elsevier/North-Holland, Amsterdam/New York.

55. Tischller, M. E., AND FAGEN, J. M. (1983) Metabolism 32, 853-868.

56. HAMMOND, G. L., WIEBEN, E., AND MARKERT, C. L. (1979) Proc. Natl Acad. Sci. USA 76, 2455-2459.

57. HaMmond, G. L., LAI, Y.-K., AND MARKeRT, C. L. (1982) Science (Washington, D. C.) 216, 529-531.

58. URIST, M. R., MiKULSKI, A., AND LIETZE, A. (1979) Proc. Natl Acad Sci USA 76, 1828-1832.

59. Boveris, A., AND ChanCE, B. (1973) Biochem. $J$. 134, 707-716.

60. Davies, K. J. A., Quintanilha, A. J., Brooks, G. A., AND PACKER, L. (1982) Biochem. Biophys. Res. Commun. 107, 1198-1205.

61. Salminen, A., AND Vihko, V. (1983) Exp. Mol. Pathoh 38, 380-388.

62. Salminen, A., AND Vihko, V. (1983) Acta Physiol Scand. 117, 109-113.

63. NAYLER, W. G. (1980) in Biomedical and Clinical Aspects of Coenzyme Q (Yamamura, Y., Folkers, K., and Ito, Y., eds.), Vol. 2, pp. 409-424, Elsevier/North-Holland, Amsterdam/New York.

64. Yamada, K., Tatsukawa, Y., Takenaka, M., IGUCHI, T., Yamamoto, M., AND KaWASAKI, T. (1980) in Biomedical and Clinical Aspects of Cocnzyme Q (Yamamura, Y., Folkers, K., and Ito, Y., eds.), Vol. 2, pp. 123-131, Elsevier/ North-Holland, Amsterdam/New York.

65. QUINN, P. J., BaUM, H., Harris, E. J., FrankLIN, C. S., AND TRIVEDI, P. in Biomedical and Clinical Aspects of Coenzyme $Q$ (Yamamura, Y., Folkers, K., and Ito, Y., eds.), Vol. 2, pp. 435-446, Elsevier/North-Holland, Amster$\mathrm{dam} / \mathrm{New}$ York.

66. Ishryama, T., Morita, Y., Toyama, S., Yamagami, T., Tsukamoto, H., Wada, N., OHKubo, M., AND Yamamura, Y. (1976) Japan. Heart J. 17, 32-42.

67. ERnster, L., AND Nelson, B. D. (1981) in Biomedical and Clinical Aspects of Coenzyme $Q$ (Folkers, K., and Yamamura, Y., eds.), Vol. 3, pp. 159-168, Elsevier/North-Holland, Amsterdam/New York. 